Article

\title{
Power in and over Cross-Sector Partnerships: Actor Strategies for Shaping Collective Decisions
}

\author{
Art Dewulf $1, *$ (i) and Willem Elbers ${ }^{2}$ \\ 1 Public Administration and Policy Group, Wageningen University and Research, 6708 PB Wageningen, \\ The Netherlands \\ 2 African Studies Centre Leiden, Leiden University, 2300 RB Leiden, The Netherlands; \\ w.j.elbers@asc.leidenuniv.nl \\ * Correspondence: art.dewulf@wur.nl
}

Received: 15 February 2018; Accepted: 8 August 2018; Published: 12 August 2018

\begin{abstract}
While cross-sector partnerships are sometimes depicted as a pragmatic problem solving arrangements devoid of politics and power, they are often characterized by power dynamics. Asymmetries in power can have a range of undesirable consequences as low-power actors may be co-opted, ignored, over-ruled, or excluded by dominant parties. As of yet, there has been relatively little conceptual work on the power strategies that actors in cross-sector partnerships deploy to shape collective decisions to their own advantage. Insights from across the literatures on multiparty collaboration, cross-sector partnerships, interactive governance, collaborative governance, and network governance, are integrated into a theoretical framework for empirically analyzing power sources (resources, discursive legitimacy, authority) and power strategies (power over and power in cross-sector partnerships). Three inter-related claims are central to our argument: (1) the intersection between the issue field addressed in the partnership and an actor's institutional field shape the power sources available to an actor; (2) an actor can mobilize these power sources directly in strategies to achieve power in cross-sector partnerships; and, (3) an actor can also mobilize these power sources indirectly, through setting the rules of the game, to achieve power over partnerships. The framework analytically connects power dynamics to their broader institutional setting and allows for spelling out how sources of power are used in direct and indirect power strategies that steer the course of cross-sector partnerships. The resulting conceptual framework provides the groundwork for pursuing new lines of empirical inquiry into power dynamics in cross-sector partnerships.
\end{abstract}

Keywords: cross-sector partnerships; institutional fields; issue field; collaboration; power sources; power strategies

\section{Introduction}

Processes of globalization have resulted in a wide range of societal problems, which, due to their complexity, can no longer be solved by one actor alone. This new reality requires different kinds of actors, such as governmental agencies, businesses, and NGOs to work together in what is variously referred to as cross-sector partnerships (Van Huijstee and Glasbergen 2010; Selsky and Parker 2005), multiparty collaboration (Gray 1985, 2011; Vangen et al. 2015; Vansina et al. 1998), collaborative governance (Ansell and Gash 2007; Emerson et al. 2012; Huxham et al. 2000), interactive governance (Edelenbos 2005; Torfing et al. 2012a), or network governance (Hajer and Versteeg 2005; Koppenjan and Klijn 2016; Klijn et al. 1995; Provan and Kenis 2007; Sørensen and Torfing 2007).

Cross-sector partnerships have become common practice over the last decades (Gray and Purdy 2018) and range from formal roundtables aiming for certification processes at the global level (e.g., Schouten et al. 2012), to informal coordination mechanisms to manage natural resources at the 
local level (e.g., Visseren-Hamakers et al. 2010). While cross-sector partnerships are highly diverse in terms of design and objectives, they are characterized by collective decision-making in which a plurality of government, business, and civil society actors are involved (Gray 2007; Selsky and Parker 2005).

Despite evidence that cross-sector partnerships are quite challenging and demanding, once summarized in the principle "don't do it unless you have to" (Huxham and Vangen 2005), they are promoted globally as a 'magic bullet' to deal with complex societal problems. Cross-sector collaboration is often viewed as a straightforward way 'to get things done' through consensus-seeking interaction among relevant and affected actors who share information, authority, and legitimacy (Torfing et al. 2012a, p. 51). The misguided assumption that by merely putting the right people in one room, a workable solution for everybody will emerge, leads people to believe that cross-sector partnerships are power-free processes, in which technical or consensual solutions can be found without dissent or opposition (Torfing et al. 2012a, p. 68). When promoting the concept, partnership enthusiasts often argue that, because of the interdependence of actors in solving the complex issue at stake, cross-sector partnerships will automatically create trust-based relations that result in synergy and enable the active participation of all. In addition, they are associated with flexibility, innovation, low transaction costs, and cross-sectoral learning. The call for cross-sector partnerships is strongly voiced and endorsed by world leaders, governments, and international organizations.

While cross-sector partnerships are sometimes depicted as a pragmatic 'problem solving' arrangements devoid of politics and power, they are characterized by power dynamics (Elbers and Schulpen 2013; Hardy and Phillips 1998; Hendriks 2009; Purdy 2012). Actors in partnerships tend to differ in terms of their control over resources while their interests are diverse and the stakes are high. When power relations are so asymmetric that one of the actors can basically impose its will on the others, one could argue that a partnership approach simply does not apply, and that trying to set up a partnership in those conditions would be ill-advised because the interdependencies linking the actors are missing (Gray and Purdy 2018). However, even when interdependencies between all actors form a good starting point for a cross-sector partnership, dependencies are unlikely to be balanced in all directions, so power imbalances are almost unavoidable (Purdy 2012). Even in situations with clear interdependencies between all actors, partnerships run the risk of becoming arenas for conflict and power struggles (Gray 2004; Purdy 2012).

The power imbalances within cross-sector partnerships are potentially problematic as less powerful actors run the risk of being ignored, overruled, or excluded. There is a growing concern that cross-sector partnerships, as instruments for solving complex societal problems, will not live up to their expectation if power asymmetries are not managed (Purdy 2012). Such asymmetries are said to undermine effectiveness and reduce the likelihood of synergy, trust, and creativity (Hardy and Phillips 1998, p. 218). If the voices of some parties are left out, important pieces of information may be missing from the discussion. More importantly, less powerful actors may be co-opted or excluded from the decision-making table, while decisions may be biased to those with greater resources (Gray 2004; Phillips et al. 2000; Purdy 2012). In such cases, the outcomes of the cross-sector partnerships will not reflect the interests and needs of less powerful actors. Moreover, actors, such as NGOs or community organizations, risk losing their credibility, as they will be held accountable for the cross-sector partnership's outcomes by other actors and by their constituency. Finally, power asymmetries contrast with the normative ideal of collaborative decision-making where all parties involved have equal opportunity to voice their concerns.

While power imbalances play a crucial role in shaping the processes and outcomes of cross-sector partnerships, these issues are often overlooked and they remain generally poorly understood in the literature (Gray 2004; Hardy and Phillips 1998; Purdy 2012; Torfing et al. 2012b). To our understanding, the current theoretical literature dealing with cross-sector partnerships is characterized by at least three limitations: (1) existing frameworks that are proposed for analyzing power within cross-sector partnerships remain at a high level of abstraction making them less useful for empirical research; (2) existing studies do not systematically distinguish between direct power strategies (which 
produce effects immediately) and indirect power strategies (setting the rules that regulate cross-sector partnerships); and, (3) power dynamics tend to be analyzed without considering the institutional environment in which cross-sector partnerships are embedded. Yet, actors draw upon the institutional context while exercising power within inter-organizational relations (Phillips et al. 2000, p. 30).

This paper seeks to address the above limitations and aims to contribute to the literature by offering a theoretical framework for empirically analyzing how power shapes the outcomes of cross-sector partnerships. Our framework clarifies (1) the nature of the power dynamics within partnerships (through the lens of actor-based, or episodic power), and (2) how these dynamics are influenced by the broader institutional environment of institutional fields and issue fields (using a structural, or systemic, power perspective). Our framework connects the so-called pluralist tradition of the political sciences, which views the exercise of power as a strategic act initiated by actors to advance certain interests, with a view of power that resonates with (post-)structuralist theorists (Foucault 1977; Laclau and Mouffe 1985). The latter tradition emphasizes the power of social structures as opposed to that of actors through self-regulation and internalized constraints.

Our framework bridges disciplinary boundaries and draws on theoretical work on power from different disciplines, including organizational psychology, public administration, organizational science, international relations, and political science. We have built our framework by bringing together insights from the following related, but parallel, literatures: (1) multiparty collaboration, originating in organisational psychology studies of conflict and negotiation in inter-organisational relations; (2) cross-sector partnerships, originating in the business and management literature, with a particular interest in business-NGO partnerships; and, (3) the governance literature originating in public administration and political science, emphasizing how governments engage with non-state actors in interactive, networked, and/or collaborative modes of governance. In building the framework, we rely on insights on power dynamics from each of these three literatures. The framework results in a number of guiding analytical questions that are essential for understanding power in cross-sector partnerships.

\section{Conceptualizing Power in Cross-Sector Partnerships}

Power is a contested concept and in the literature a variety of definitions and approaches can be found (Bachrach and Baratz 1962; Bourdieu 1989; Castells 2011; Clegg 1989; Dahl 1957; Emerson 1962; Fairclough 1992; Hayward and Lukes 2008; Pettit 2010). Some define power in terms of having resources; others focus on the effects it produces. For some theorists, power is intentional, while others emphasize that power also works unintentionally. For some power is always against the will of others, while others emphasize the power of persuasion, arguing and the possibility of granting power. Some theorists situate power at the level of the actor, while others situate power at the level of structure. Some view power as a zero-sum game (A achieves something at the expense of B), while others relate to achieving collective outcomes. Overall, there is no agreement in the literature on what power is or what dimensions it has.

The complexity of the power concept means that any framework that is designed for empirical analysis must start by situating itself in the literature and offering conceptual clarity. Our starting point is an understanding of power as "the ability to shape and secure particular outcomes" (Torfing et al. 2012b, p. 48). Because collective decision-making is at the core of cross-sector partnerships, power can here be understood more specifically as the ability of individual actors to influence collective decisions of the partnership to their own advantage, in a variety of different ways. The addition of "to their own advantage" signals that our focus is on "power over" others, rather than the more general capacity of "power to" achieve things (Anthony 1984; Gray and Purdy 2018), the power of working together expressed as "power with" others (Gaventa 2006), or the "power for" others that goes beyond self-interest, by aiming for balancing power relations or empowering actors (Huxham and Vangen 2005). In focusing on the ability of individual actors to influence collective decisions of the partnership to their own advantage, we make a distinction between having power and exercising power (Nye 1990). Having power refers to the ability that an actor has to get others to act 
in line with one's preferences or interests (Dahl 1957, pp. 202-3). Thus, having power is about being able to enforce one's own intentions, interests, preferences, or will, over those of others, in this case, in the context of cross-sector partnerships. Exercising power, also referred to as influence, refers to actors' actual use of their capacity to get others to change their behavior and thus generate an effect. This distinction is relevant because there is no one-to-one relationship between having and exercising power. An actor with a lot of capacity may still have little political influence, while an actor with seemingly little resources may still be very influential, depending on when and how actors decide to use their capacities.

Within cross-sector partnerships that are characterized by some degree of institutionalization (Gray 2004), power refers to the capacity of individuals and groups to influence the outcomes of collective decision-making processes and to benefit from those decisions (Phillips et al. 2000). It is not hard to see that power lies at the basis of political inequality within cross-sector partnerships: by being able to dominate the outcomes of decision-making processes in partnerships, resulting policies and practices may end up favoring the needs and interests of certain actors at the expense of others. We will see below that political inequality in cross-sector partnerships also means that not all actors have equal opportunities to participate in the decision-making in the first place (Nye 1990).

The ability of individual actors to influence collective decisions of the partnership to their own advantage can take a variety of forms. While emphasis in the partnership literature is often on direct power that is based on resource dependencies (Emerson 1962; Emery and Trist 1965; Pfeffer and Salancik 2003; Scharpf 1978), indirect and ideological forms of power are equally important. In the power literature, a distinction is often made between three different faces of power (Bachrach and Baratz 1962; Hayward and Lukes 2008; Torfing et al. 2012b), which can be summarized, as follows: (1) direct power: the ability of actor A, in open conflict with actor B, to make actor B do something that B would otherwise not have done; (2) indirect power: the ability of actor A to regulate and control the decision-making agenda, suppressing issues and proposals promoted by actor B; and, (3) ideological power: the ability of actor A to manipulate actor B's subjective perception of his or her interests, thereby avoiding conflicts altogether. The three faces of power are forms of 'episodic power' and capture the ways actors exercise power over other actors (Gray and Purdy 2018; Lawrence 2008). In this paper, we also take into account the 'systemic power' that is 'exercised' by structures, which is sometimes referred to as a fourth face of power (Torfing et al. 2012b) This form of power is embedded in on-going, taken-for-granted practices and understandings that advantage some groups over others (Gray and Purdy 2018; Lawrence 2008). The framework that we outline below clarifies how episodic forms of power are enabled or constrained by systemic power, embedded in institutional fields and issue fields (Gray and Purdy 2018).

Fundamental to our argument is the conceptualization of power and interactive governance (Torfing et al. 2012b) that analyzes the relations between interactive governance and the broader governance context in terms of power in, of, over, and as interactive governance. This relation can be analyzed in terms of "power in interactive governance" (multi-actor view of power struggles between actors within an interactive governance arena), but also in terms of "power of interactive governance" (ability of interactive governance arenas to influence the social and political environment), "power over interactive governance" (ability of governments and other actors to shape and regulate interactive governance arenas"), and "power as interactive governance" (interactive forms of governance as a particular historical form of power in advanced liberal societies, through the mobilization of autonomous actors in self-regulating governance arenas).

Given our focus on the ability of individual actors to influence collective decisions of the partnership to their own advantage, and translating these concepts to cross-sector partnerships, our interest is mainly in "power in cross-sector partnerships" (power in CSPS) and "power over cross-sector partnerships" (power over CSPS). While most attention has been payed to power in CSPS, the perspective of power over CSPS brings different mechanisms into the picture through which actors can influence collective decisions to their own advantage. These include initiating and terminating partnerships, 
regulating access to partnerships, framing the type of interaction, or assessing the performance of partnerships (Torfing et al. 2012b).

The ability of actors to exercise power in and over CSPS depends on the sources of power they have at their disposal. Three sources of power have been consistently mentioned in the collaboration literature and constitute another important foundation for our framework: resources, discursive legitimacy, and authority (Gray and Purdy 2018; Hardy and Phillips 1998; Phillips et al. 2000; Purdy 2012). Resource-based power builds on the dependencies among actors and their access to resources like finance, technology, knowledge, or human resources. Each actor brings in its own set of resources, yet not all resources are of equal value. In those cases where actors depend on others for critical resources, the resource-rich party has a strong source of power at its disposal. Discursive legitimacy refers to the ability of an actor to represent a particular view, or speak on behalf of an issue in the cross-sector partnership. For example, actors can be in the position to speak legitimately on behalf of economic rationality, ecological conservation, or the respect for diverse cultures. Authority is the socially acknowledged right to take action or make decisions based on position within hierarchical settings, and it relates to the relative status of actors in the institutional field in which the participating parties are embedded. While actors may have a variety of power sources at their disposal this does not mean they will actually deploy them to create an effect. Cross-sector partnerships will often try to ask more powerful actors not to use all of the power sources at their disposal during the course of the cross-sector partnership, or to strengthen the power position of less powerful actors through providing funding or capacity building.

\section{Institutional Fields, Issue Fields and Systemic Power}

To understand how power dynamics in cross-sector partnerships are shaped by the broader environment in which they are positioned, we draw upon the related concepts of issue fields and institutional fields (Gray and Purdy 2018).

An issue field, also known as an inter-organizational problem domain (Gray and Purdy 2018; Trist 1983), refers to a meta-problem that requires inter-organizational response capability. It is comprised of a set of issues that are related to the meta-problem, and a set of actors who have an interest in these issues. Meta-problems are not clearly defined individual problems, but rather 'messes' of interrelated problems that are hard to pin down or delineate (Trist 1983). Examples of meta-problems could be urban homelessness (involving issues of poverty, housing, health care, etc.) or water pollution (involving issues of industry emissions, agricultural practices, biodiversity, etc.). Interdependencies between actors in an issue field provide the potential for collaboration as well as for conflict.

Actors in partnerships have different backgrounds and represent different types of organizations, even more so in the case of cross-sectoral partnerships. The concept of institutional field, coming from organisational institutionalism (DiMaggio and Powell 1983), provides a way of capturing those different backgrounds and their effects on cross-sector collaboration. An institutional field can be defined as a 'recognized area of institutional life' (DiMaggio and Powell 1983, p. 83) in which there is 'a community of organizations that partakes of a common meaning system and whose participants interact more frequently and fatefully with one another than with actors outside the field' (Scott 2008, p. 84). The underlying assumption here is that organisations understand themselves and the world based on shared, and often taken for granted and internalized, belief systems that are learned and maintained through the membership of a given institutional field.

Institutional fields develop through the process of structuration (Anthony 1984), which refers to the interaction between actors that produce and reproduce, the belief systems and practices that constitute the field (DiMaggio and Powell 1983; Lawrence et al. 2002; Scott 2008). Through repeated interactions, groups of organizations develop common understandings and practices that define the field. Actors draw upon the belief systems and accepted practices of their respective institutional field for guidance, meaning, and legitimacy (Phillips et al. 2000, p. 29). The institutional field provides 
organisations with collective identities, motives, and vocabularies while offering guidance with regard to which problems get attended to, which solutions get considered, what outcomes are to be achieved, and what practices are considered (Townley 1997, p. 263; Thornton and Ocasio 2008, pp. 111-14; Greenwood et al. 2002, p. 59). This implies that the preferences and interests of organisations are seen as socially constructed and varying by institutional context.

Actors in cross-sector partnerships bring with them sets of ideas and languages and practices that are institutionalized with their respective fields (Meyer and Rowan 1977). This means that the range of institutional fields from which actors originate has a major impact on the collaboration (Phillips et al. 2000, p. 28). The more different fields are brought together within a cross-sector partnership, the more values, languages, and working practices enter the cross-sector partnership and the more complex cooperation becomes. This can be a cause for friction as multiple belief systems and standards may be in conflict with each other.

In our view, the concepts of issue field and organizational fields need to be better distinguished, and analyzed in combination, in order to understand how the systemic power embedded in these fields shapes the sources of power that actors have at their disposal for episodic power strategies (see Figure 1). In combination, the concepts of issue field and institutional field help to understand how the broader institutional environment carries systemic power that shapes the power dynamics within cross-sector partnerships. It is at the intersection of institutional fields and a particular issue field that systemic power shapes the power sources that actors can mobilize in episodic power strategies. The starting situation for a cross-sector partnership is usually a weakly institutionalized issue field, with its patterns of dependencies, power relations, and conflicts of interest between actors. The partnership then engages a set of actors of this issue field into direct interaction and collective decision-making, thereby confronting multiple institutional fields that shape the identities, motives, and vocabularies of these multiple actors, in relation to this particular issue field. It makes a difference whether the issue field constitutes the core business versus a secondary concern for an individual actor. The power sources (resources, authority, discursive legitimacy) that are available to an actor in a particular partnership are shaped by this intersection. For example, a large food corporation may have huge amounts of financial resources available, e.g., for investing in new product development, but prevailing norms, rules and meanings from its institutional field may limit the amount of resources the organization can actually invest when the partnership addresses an issue field like improving the local education infrastructure in overseas producer communities. Similarly, the authority that a Ministry of Environment is granted within its own institutional field does not necessarily constitute a strong source of power in a partnership that addresses an issue field, like innovating agricultural technology, although it may have a clear interest in the issue field. As another example, the discursive legitimacy of a nature conservation organization to speak on behalf of the natural environment will likely be higher than when it speaks on behalf of poor communities. It depends on the nature of the issue that a partnership seeks to address whether power sources can actually be 'converted' to real influence. Actors draw upon the power sources (e.g., resources, discursive legitimacy, authority) from their respective institutional fields to achieve their goals within cross-sector partnerships. How much power different sources provide, however, is always context-dependent (Clegg 1989). Consequently, the power that certain resources provide in a given institutional field may not translate to the same extent in a cross-sector collaboration. The more the institutional field and the issue are aligned, the greater the likelihood that resources translate to actual power within a partnership.

The above implies a more pervasive and less tangible form of power that cannot be attributed to the strategic acts of self-interested actors. This form of power, which in the literature is often referred to as systemic power, is inherent in the structures of signification pertaining to an institutional field, and shape the identity, motives, and interests of actors in relation to a particular issue field (Lawrence 2008, p. 174), leading to a specific set of power sources (resources, authority, discursive legitimacy) available to each of the actors in a cross-sector partnership. 


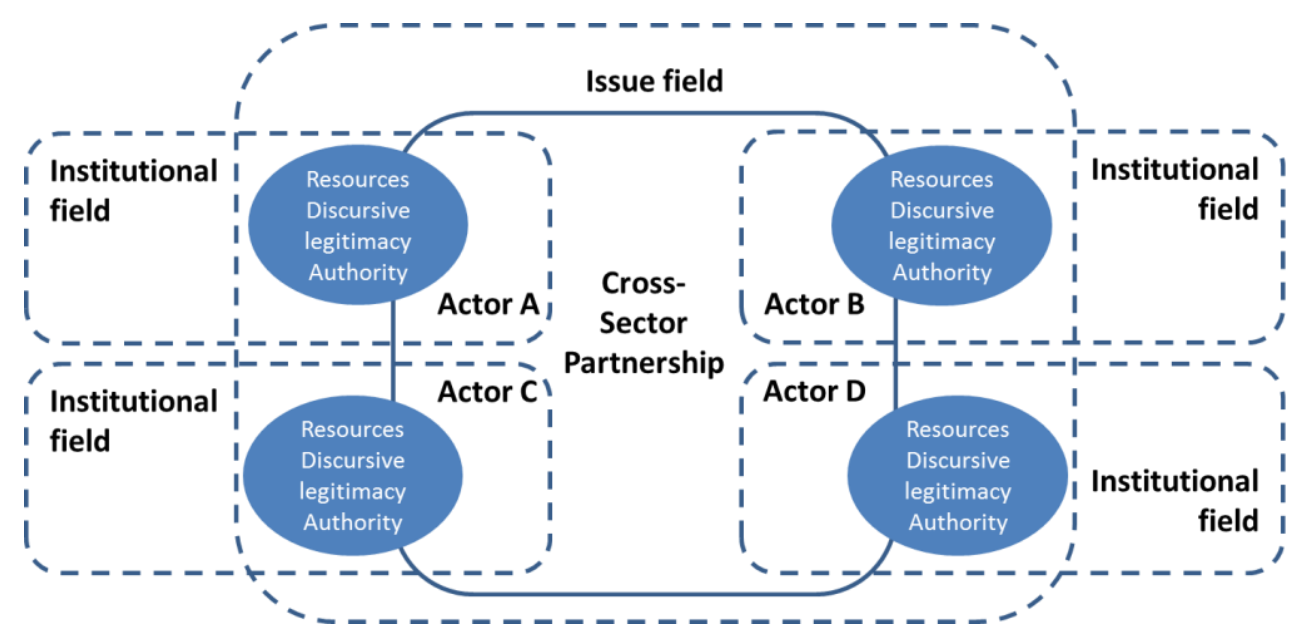

Figure 1. Power sources at the intersection of issue field and institutional fields.

\section{Sources of Power and Episodic Power Strategies}

The outcomes of cross-sector partnerships for an important part are determined by power games in which actors try to influence collective decisions. Starting from the intersection of issue field and institutional fields, Figure 2 gives an overview of how available power sources can be mobilized for episodic power strategies of two different types: power over CSPS and power in CSPS.

When actors exercise power, the resources, discursive legitimacy, and/or authority they dispose of are used in episodic power strategies in an effort to steer the behavior of other actors and as such the course of the cross-sector partnership. There are two levels at which these efforts can be oriented: (1) power in CSPS and (2) power over CSPS (Torfing et al. 2012b). At the level of power in CSPs, actors use direct power strategies to influence each other and the outcomes of the cross-sector partnership directly. At the level of power over CSPs, actors use indirect power strategies to set or change the rules of the game. Once these rules have been set, they continue to influence the actors within the cross-sector partnership and its course and outcomes (Klijn 2001).

Power in CSPs. Direct power strategies mobilize resources, discursive legitimacy, and/or authority to shape and secure collective decisions in the cross-sector partnership. Resources can be mobilized and exchanged for achieving agreements about outcomes, giving the actors disposing of better resources an advantage in the partnership game. The meaning and implications of partnership goals, knowledge, or problem definitions can be shaped and reshaped in processes of interactive and strategic framing, giving the actors disposing of greater discursive legitimacy or persuasive skills an advantage. Finally, authority deriving from one's position in the partnership (e.g., convener) or in the broader institutional field (e.g., policy maker or CEO) can be mobilized to push claims, preferences, or proposals through.

Power over CSPs. Rules allow for power to be exercised indirectly in the sense that they influence behavior beyond the current moment (Clegg 1989, p. 213). Once established, rules continue to shape the future choices of actors. Indirect power strategies mobilize resources, discursive legitimacy, and/or authority to shape and secure the rules of the game, thereby indirectly influencing the cross-sector partnership actors and outcomes. Starting or continuing a partnership in itself requires resources, and actors who are able to invest these resources can take advantage of this to set the rules of the game for the cross-sector partnership. Actors that have access to high discursive legitimacy in the broader institutional field can obtain easier access to the partnership or can influence how the scope of the problem to be addressed gets framed. Authority can also be mobilized to set the rules for the partnership in terms of access (who is in and who is out) and decision-making (e.g., decision by consensus or majority). 


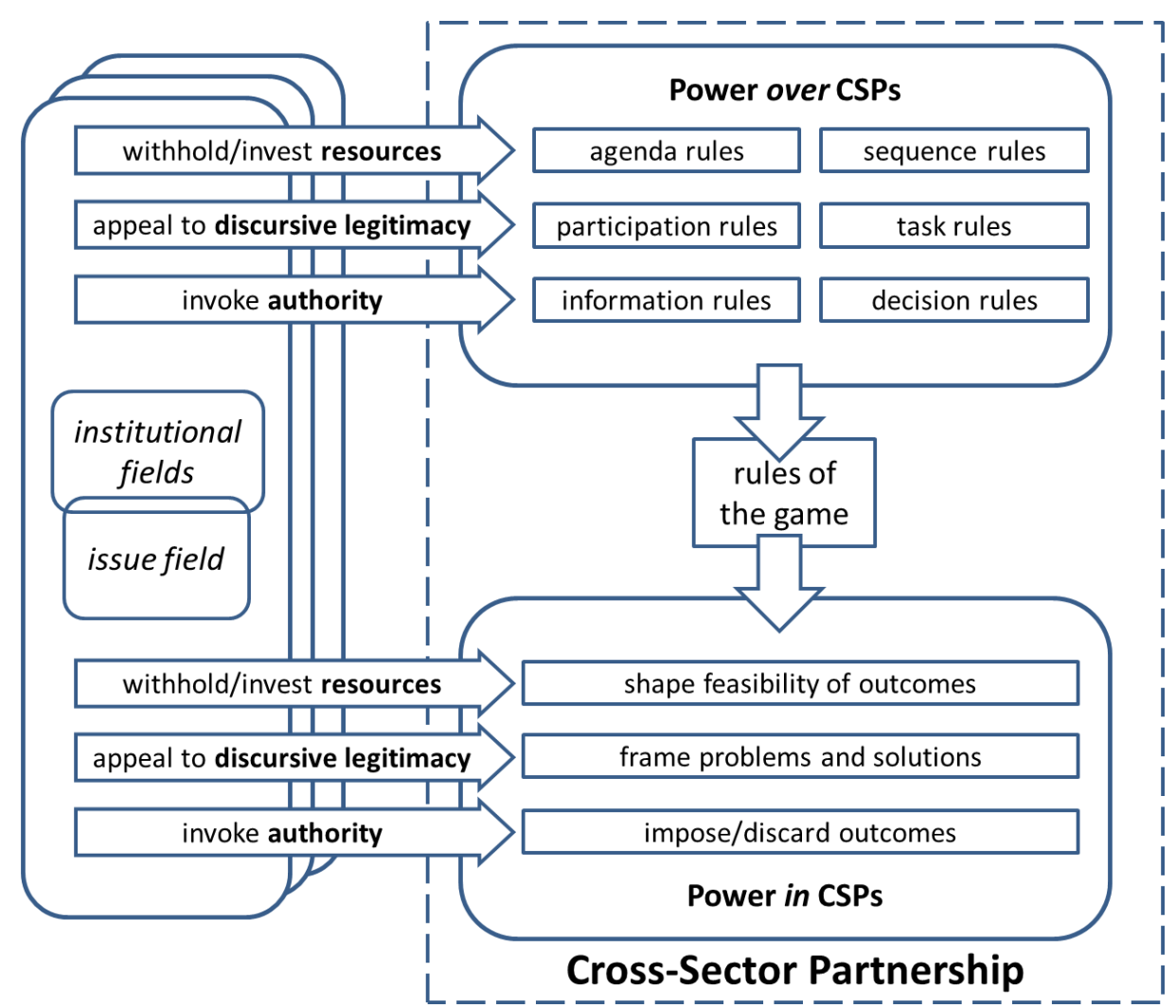

Figure 2. Mobilizing sources of power in strategies for exercising power in and over CSPs.

\section{Strategies for Exercising Power in CSPs}

In the context of cross-sector partnerships, actors use a variety of strategies to directly exercise power over each other to influence collective agreements. Three strategies are prominent, which are directly linked to the power sources actors have at their disposal: (1) withholding/investing resources; (2) appealing to discursive legitimacy; and (3) invoking authority.

\subsection{Withold/Invest Resources to Shape Feasibility of Collective Decisions}

Within the context of partnerships, actors' influence is strongly based on relations of resource (inter)dependence (Pfeffer and Salancik 2003). In inter-organizational domains, actors depend upon each other for material and immaterial resources, such as money, expertise, information, or contacts to achieve their goals and ensure their survival. Within these relations, each actor brings in its own set of resources, depending on the institutional field in which the actor is embedded. Yet, not all resources are of equal value, leading to relations of autonomy and dependence between actors. When the control of critical resources is diffused among actors and a lot of interdependencies are at play, the collaboration will likely involve greater levels of negotiation, compromise, and pooling of resources (Bouwen and Taillieu 2004; Hardy and Phillips 1998).

In those cases where actors depend on others for critical resources, the resource-rich party is in a strong position to influence collective decisions by withholding resources versus committing to invest resources-assuming that the availability of those resources determines the feasibility of the involved decisions. This way, the desire for resources or the fear of having them withheld ensures the obedience of those being influenced. Pfeffer and Salancik (2003, pp. 45-51) identify three crucial factors for determining the dependence of one actor on another: (1) resource importance-the extent to which a resource is needed by an actor for organizational survival; (2) discretion over resource allocation and use- the degree to which an actor can control how the resource received from another actor is 
allocated and used; and, (3) concentration of resource control—the extent to which alternative sources of a resource are available and accessible.

\subsection{Appeal to Discursive Legitimacy to Frame Collective Decisions}

Another important source of power in playing the partnership game is discursive legitimacy (Hardy and Phillips 1998; Purdy 2012). This refers to an actors' ability to speak legitimately for issues or other organizations to influence what situations, issues, or solutions are taken to mean. We try to grasp this aspect through the concept of interactional framing (Dewulf et al. 2009) and collective sense-making (Van Buuren et al. 2014; Vink 2015). From a framing perspective (Schön and Rein 1994; Stone 2002; Van Hulst and Yanow 2014), decision-making in partnerships is shaped by the 'contest over the framing of ideas' through 'selecting, organising, interpreting and making sense of a complex reality to provide guideposts for knowing, analysing, persuading and acting' (Schön and Rein 1994, p. 146). These frames often take shape as short storylines or metaphors, explicitly or implicitly saying something about the cause of the often problematic reality, taking a normative standpoint towards this reality and pointing towards possible solutions.

Taking an interactional framing approach, playing the partnership game involves the interactive alignment of meaning in a process of sensemaking (Weick 1995). In this paradigm, framing refers to a highly dynamic process of actors continuously negotiating over meaning through language. Since each participant co-develops the discussion, they negotiate the relevant framing on the spot, relying on different frame interaction strategies to include or exclude particular ways of framing the issue (Dewulf and Bouwen 2012). Whoever is able to get his or her frame adopted by other actors is setting the terms for the further debate and thereby influencing collective decisions. Interactional framing can therefore be understood as the interplay between puzzling over ideas and powering over interests, through mobilizing power sources, such as discursive legitimacy from the broader institutional field.

\subsection{Invoking Authority to Impose/Discard Collective Decisions}

Authority as the socially acknowledged right to exercise judgment, make a decision, or take action (Purdy 2012) can derive from one's position in the cross-sector partnership (e.g., convener) or one's position in the broader institutional field (e.g., policy maker, CEO or scientist). Furthermore, within cross-sector partnerships, it is common to have designated 'lead organizations' specified, for example, by an external funder or government policy. By assuming the position of designated lead organization status, actors are in a privileged position to influence collective decisions process.

Invoking authority often sits uncomfortably with the assumption of many partnerships that all actors should have an equal say in the cross-sector deliberations. Open and explicit appeals to authority are therefore not very likely to occur publicly in cross-sector partnerships, but more implicit references to one's position and its accompanying authority are commonly observed. Statements on substantive issues but clearly referencing one's position are good examples, e.g., "as conveners of this partnership, we propose..." or "given our responsibility for the national policy framework, we want to put forward..." (Dewulf et al. 2005). While away from the negotiation table and outside of public scrutiny, more direct appeals to authority can be made in e.g., bilateral talks, e.g., when government actors try to overrule others by stating that a certain proposal will not stand a chance in the current policy framework.

\section{Strategies for Exercising Power over CSPs}

Power games in cross-sector partnerships take place within sets of rules that provide a framework within which concrete interactions can take place (Klijn 2001). These rules both enable and constrain behavior by defining what actors are allowed, required, and not allowed to do. They bring stability and predictability to the partnership game by regulating interactions. Rules can be formal and informal. While formal rules are fixed and authorized in legal texts (e.g., laws, MoUs, contracts), informal rules have a more tacit character and often achieve a 'taken for granted' status (Anthony 1984; Klijn 2001; 
Koppenjan and Klijn 2016). Once established, rules have a profound impact on what actors do and do not do in the cross-sector partnership.

Exercising power over CSPS is possible through setting the rules of the game for a partnership, e.g., by defining the substantive scope, by selecting the actors, or by setting decision-making rules (Elbers and Schulpen 2013). As such, an important part of the power game relates to actors' efforts to manipulate the rules to their advantage and thereby indirectly influencing the partnership game. These strategies for achieving power over CSPS, which aim at shaping the game through setting the rules, are of crucial relevance at the start of a partnership, but can, given the often fluid and ambiguous nature of cross-sector partnerships (Huxham and Vangen 2000), actually be deployed at any stage of a cross-sector collaboration. When compared to the direct exercise of power associated with episodic power, such indirect power strategies can considered to be equally effective and probably less visible. Barnett and Duvall (2005, p. 52) refer to rules as 'frozen configurations of privilege and bias', which continue to shape the future actions of actors long after they have been established.

Which rules are of relevance to cross-sector partnerships? Different authors have proposed rule typologies (e.g., Burns and Flam 1987; Ostrom 2011). The set of rules that was proposed by Koppenjan and Klijn (2016) are particularly useful for the purpose of this paper as they explicitly deal with interactions and processes within cross-sector collaboration:

- Participation rules define who can participate, under what conditions, and in which roles. Inclusion and exclusion is an important mechanism of power. Through influencing participation rules, actors can try to get their preferred partners on board, or to keep their adversaries out of the partnership. Participation rules also define in what capacity actors participate: as key actors, as beneficiaries, as experts, as implementers, etc., shaping their power relations within the partnership.

- Agenda rules relate to the scope and objectives of the partnership. They define the mission and identity of the joint undertaking and the issues that will and will not be addressed. Through influencing agenda rules, actors can secure sufficient attention for they key issues in the partnership, or conversely, keep important issues off the negotiation table such that no collective decisions are made regarding these issues. Keeping issues of the table is a form of "nondecision-making" (Bachrach and Baratz 1962) that can advantage actors who benefit more from the current situation than from a major change.

- Sequence rules define the steps to be taken in the interaction process, for example, which steps to take for mapping the problem, how soon or how late in the process are specific solutions discussed, how much time to reserve for representatives to consult with their constituencies, etc. Setting deadlines is an important way of putting pressure on the process and pushing reluctant actors to commit to a collective decision.

- Task rules define the structuring of activities within the partnership. They may concern the division of labor between the parties, for example through installing a steering group or working groups for particular issues. Task rules can also define practical things, like work methods or which information and communication systems to use to work together. Through setting task rules, actors can try to position their priority issues or decision proposals as the key topic of a working group, for example, or to propose an sophisticated on-line collaboration environment in which only certain actors are proficient, giving them an advantage in directing the flow of information.

- Information rules define how to use information and whether and how information will be shared with others. Actors may have different interests regarding transparency versus confidentiality of information towards to outside world. Media attention can advantage some actors and disadvantage other actors in their negotiation positions. Influencing information rules therefore exercises power over CSPS.

- Decision-making rules define how decisions are going to be made in the partnership. Specifying what will be considered as a decision (verbal agreement during a meeting, action point mentioned in the minutes of meeting, or only an officially signed agreement), how decisions are to be made 
(e.g., by consensus or majority), or what is allowed or required in terms of consulting with constituencies (e.g., no major decisions are taken without consulting constituencies) all shape the relative influence actors have on the collective decisions resulting from the partnership.

These rules can be implicitly adopted, unilaterally determined, or collectively negotiated and validated. Because each of these rules shape the decision-making process and indirectly the collective decisions resulting from the partnership, influencing these rules becomes a viable strategy for exercising power over CSPS.

Similar to power in CSPs, actor can mobilize available sources of power to achieve power over CSPs. Strategies to exercise power over CSPs involve influencing the rules of the game for the partnership, including participation rules, agenda rules, sequence rules, task rules, information rules, and decision-making rules. As discussed above, these episodic power strategies rely on the mobilization of resources, discursive legitimacy, and authority as sources of power, differentially available to actors because of their position in the relevant issue field and institutional fields. Although some connections are more obvious than others-e.g., invoking authority to set decision-making rules, or appealing to discursive legitimacy to set agenda rules-each of the three sources of power can potentially be mobilized to shape any of the six type of rules. Particularly at the moment of initiating a partnership, a variety of different rules are implicitly or explicitly set. Substantial financial and human resources are usually necessary to invest in the laborious start of a partnership. But, resources are not all that matters in being involved early on in partnership formation. An actor's discursive legitimacy may be so high that starting a partnership without them affects the legitimacy of the entire partnership. Or an actor's authority position in e.g., the governmental system may so crucial for the partnership's success that they are effectively unavoidable. Each of these mechanisms puts some actors in the position to be there when these rules are set, while others join only at a later stage, when a set of rules are already in use.

Being able to set or at least influence the rules that guide cross-sector partnerships is therefore a desirable goal for most actors. The rules that guide partnerships are usually set in two different ways. First, actors may decide upon the nature of the rules during the collective decision-making process. For example, actors may decide on the roles of the different members in the collaboration (participation rules) or the type of information that is shared (information rules). Second, certain actors, typically those that are in control of critical resources, may set the rules unilaterally without the involvement of others. The reality of many cross-sector partnerships, however, is that not all participants can equally participate in decision-making processes. With many cross-sector partnerships, it is common to have designated 'lead organizations' specified, for example, by an external funder or government policy. By assuming the position of designated lead organization actors are in a privileged position to set the terms of the partnerships from the onset.

\section{Discussion and Conclusions}

Power is only one dimension of cross-sector partnerships but it is a relatively understudied one. Our aim was to create a better conceptual understanding of power strategies in these partnerships, specifically of the ability of actors to influence collective decisions of the partnership to their own advantage. The result is an integrated framework on how actors can exercise power in and over CSPs. We built the framework by bridging different literatures (multiparty collaboration, cross-sector partnerships and interactive, network, and collaborative governance) and power traditions (systemic and episodic power), capturing the layered power dynamics in partnerships. We explain that actors can mobilize sources of power (by withholding/investing resources, appealing to discursive legitimacy and invoking authority) in order to exercise power directly (power in CSPS) and indirectly by setting the rules that govern the partnership (power over CSPs). Furthermore, we demonstrate that these episodic power strategies are fundamentally shaped by the intersection of the institutional fields from which actors originate and the issue field, which connects the actors in the partnership. 
The novelty of the framework itself is threefold: unlike existing frameworks it (1) offers guidance for empirical research, (2) it distinguishes between direct and indirect power strategies, and (3) it clarifies how power dynamics within cross-sector partnerships are linked to the institutional context. The relevance of our framework also lies in the guidance it offers for pursuing new lines of empirical inquiry. Based on the different analytical dimensions of the framework and the connections between them, important questions for future empirical research emerge. With respect to the power sources that are available to actors, an important question concerns the relative importance of institutional fields and issue fields in shaping the availability of power sources. For example, does a strong and stable institutional field make for a stronger impact on the available power sources relative to the issue field? Does an established issue field, rooted in a history of interactions between actors, make for a stronger impact on the available power sources relative to the institutional field an actor comes from? We have mostly considered sources of power separately, but to what extent and how the different sources of power reinforce each other or are mobilized in conjunction is another relevant question. Finally, one could test the implication of our theoretical framework that actors from similar institutional fields engaging in the same issue field should look more alike in terms of available power sources, than actors from different institutional fields. With respect to strategies for exercising power in CSPs, one could investigate whether certain types of actors exercise power predominantly through particular strategies, e.g., business actors through withholding/investing resources, government actors through invoking authority, and civil society actors through appealing to discursive legitimacy. With respect to strategies exercising power over CSPs, the relative importance of the different types of rules can be questioned: are certain types of rules more important than others in shaping ability of actors to influence collective decisions of the partnership to their own advantage? Also, the relation between the different sources of power and the different types of rules can be empirically investigated: are certain sources of power mobilized more often for setting certain types of rules. For example, are decision rules more strongly influenced by invoking authority, are agenda rules more strongly influenced by appealing to discursive legitimacy, and are sequence rules more strongly influenced by withholding/investing resources in joint activities? Finally, our framework is limited to identifying the menu of strategies available to actors. An important question that would require in-depth study of interactions in partnerships is how other actors recognize, accept, contest, or respond to these power strategies in a strategic game of moves and counter-moves.

When a cross-sector partnership is successful, it leads to concrete outcomes, generally in the form of implemented agreements among the involved actors. The question to what extent this agreement, or the cross-sector platform itself, can and should be institutionalized is an important one at that point (Gray 2007). Related to this is the question whether the cross-sector partnership effects an enduring change in the issue field and respective institutional fields, e.g., by introducing new practices or changing the relations between actors-this is the question whether institutional change has occurred. A more specific question that is related to our exploration of power in cross-sector partnerships concerns the degree to which the distribution of access to power sources has changed. Or, if one wants to ask this question in terms of empowerment, the degree to which less powerful or marginalized actors have obtained more access to power sources as a result of the partnership (Woodhill and van Vugt 2011). These questions are clearly relevant in a broader analysis of the power of cross-sector partnerships over their social and political environment (Torfing et al. 2012b), but are beyond the scope of our current analysis, and thus constitute an interesting opportunity for further elaborating the current framework.

While analyzing power dynamics in partnerships is a valid topic of inquiry in its own right, the starting-point of this paper is our concern with the inequality that characterizes many cross-sector partnerships. Inequality can only exist in situations where power is exercised, making the study of power dynamics within cross-sector partnerships an important topic for further research. Although the paper mainly has a theoretical focus, we believe that it also has practical relevance. By shedding light on the power dynamics in partnerships and clarifying why certain actors are more powerful 
than others through identifying concrete power strategies, it offers starting-points for addressing power imbalances. In addition, the framework can be used by less powerful actors to understand the opportunities, limitations, and risks that cross-sector partnerships offer. This way they can make informed decisions about whether or not to participate in particular partnerships.

Author Contributions: Both authors contributed to the theoretical thinking, literature review and writing up for each of the sections of the paper. Elbers' contribution was relatively stronger on the institutional aspects of partnerships, while Dewulf's contribution was relatively stronger on the interactional aspects of partnerships. Dewulf led the final writing up of the manuscript and its revision in response to the reviewers' comments.

Funding: This research received no external funding.

Conflicts of Interest: The authors declare no conflicts of interest.

\section{References}

Ansell, Chris, and Alison Gash. 2007. Collaborative Governance in Theory and Practice. Journal of Public Administration Research and Theory 18: 543-71. [CrossRef]

Anthony, Giddens. 1984. The Constitution of Society: Outline of the Theory of Structuration. Critique. Cambridge: Polity Press.

Bachrach, Peter, and Morton S. Baratz. 1962. Two Faces of Power. American Political Science Review 56: 947-52. [CrossRef]

Barnett, M., and R. Duvall. 2005. Power in International Politics. International Organization 59: 39-75. [CrossRef]

Bourdieu, Pierre. 1989. Social space and symbolic power. Sociological Theory 7: 14-25. [CrossRef]

Bouwen, Rene, and Tharsi Taillieu. 2004. Multi-party collaboration as social learning for interdependence: Developing relational knowing for sustainable natural resource management. Journal of Community $\mathcal{E}$ Applied Social Psychology 14: 137-53. [CrossRef]

Burns, Tom R., and H. Flam. 1987. The Shaping of Social Organization: Social Rule System Theory with Applications. London: Sage.

Castells, Manuel. 2011. A network theory of power. International Journal of Communication 5: 773-87.

Clegg, Stewart R. 1989. Frameworks of Power. London: Sage.

Dahl, Robert A. 1957. The concept of power. Behavioral Science 2: 201-15. [CrossRef]

Dewulf, Art, and René Bouwen. 2012. Issue Framing in Conversations for Change: Discursive Interaction Strategies for "Doing Differences". The Journal of Applied Behavioral Science 48: 168-93. [CrossRef]

Dewulf, Art, Marc Craps, René Bouwen, Tharsi Taillieu, and C. Pahl-Wostl. 2005. Integrated management of natural resources: Dealing with ambiguous issues, multiple actors and diverging frames. Water Science and Technology 52: 115-24. [CrossRef] [PubMed]

Dewulf, Art, Barbara Gray, Linda Putnam, Roy Lewicki, Noelle Aarts, Rene Bouwen, and Cees Van Woerkum. 2009. Disentangling approaches to framing in conflict and negotiation research: A meta-paradigmatic perspective. Human Relations 62: 155-93. [CrossRef]

DiMaggio, Paul J., and Walter W. Powell. 1983. The iron cage revisited: Institutional isomorphism and collective rationality in organizational fields. American Sociological Review 48: 147-60. [CrossRef]

Edelenbos, Jurian. 2005. Institutional Implications of Interactive Governance: Insights from Dutch Practice. Governance 18: 111-34. [CrossRef]

Elbers, Willem, and Lau Schulpen. 2013. Corridors of Power: The Institutional Design of North-South NGO Partnerships. VOLUNTAS: International Journal of Voluntary and Nonprofit Organizations 24: 48-67. [CrossRef]

Emerson, Kirk, Tina Nabatchi, and Stephen Balogh. 2012. An Integrative Framework for Collaborative Governance. Journal of Public Administration Research and Theory 22: 1-29. [CrossRef]

Emerson, Richard M. 1962. Power-Dependence Relations. American Sociological Review 27: 31-41. [CrossRef]

Emery, Fred E., and Eric L. Trist. 1965. The causal texture of organizational environments. Human Relations 18: 21-32. [CrossRef]

Fairclough, Norman. 1992. Discourse and Power. In Language and Power. London: Sage, pp. 43-76.

Foucault, Michel. 1977. Discipline and Punish. New York: Pantheon.

Gaventa, John. 2006. Finding the Spaces for Change: A Power Analysis. IDS Bulletin 37: 23-33. [CrossRef] 
Gray, Barbara. 1985. Conditions facilitating inter-organizational collaboration. Human Relations 38: $173-84$. [CrossRef]

Gray, Barbara. 2004. Strong opposition: Frame-based resistance to collaboration. Journal of Community E Applied Social Psychology 14: 166-76. [CrossRef]

Gray, Barbara. 2007. The process of partnership construction: Anticipating obstacles and enhancing the likelihood of successful partnerships for sustainable development. In Partnerships, Governance and Sustainable Development. Edited by P. Glasbergen, F. Biermann and A. P. J. Mol. Cheltenham: Edward Elgar.

Gray, Barbara. 2011. The Complexity of Multiparty Negotiations: Wading into the Muck. Negotiation and Conflict Management Research 4: 169-77. [CrossRef]

Gray, Barbara, and Jill Purdy. 2018. Collaborating for Our Future. Multi-Stakeholder Partnerships for Solving Complex Problems. Oxford: University Press.

Greenwood, R., R. Suddaby, and C. R. Hinings. 2002. Theorizing change: The role of professional associations in the transformation of institutionalized fields. Academy of Management Journal 45: 58-80.

Hajer, Maarten, and Wytske Versteeg. 2005. Performing Governance through Networks. European Political Science 4: 340-47. [CrossRef]

Hardy, Cynthia, and Nelson Phillips. 1998. Strategies of engagement: Lessons from the critical examination of collaboration and conflict in an interorganizational domain. Organization 9: 217-30. [CrossRef]

Hayward, Clarissa, and Steven Lukes. 2008. Nobody to shoot? Power, structure, and agency: A dialogue. Journal of Power 1: 5-20. [CrossRef]

Hendriks, Carolyn M. 2009. Deliberative governance in the context of power. Policy and Society 28: 173-84. [CrossRef]

Huxham, Chris, and Siv Vangen. 2000. Ambiguity, complexity and dynamics in the membership of collaboration. Human Relations 53: 771-806. [CrossRef]

Huxham, Chris, and Siv Vangen. 2005. The principles of the theory of collaborative advantage. In Managing to Collaborate. The Theory and Practice of Collaborative Advantage. Abingdon: Routledge, pp. 30-42.

Huxham, Chris, Siv Vangen, Christine Huxham, and Colin Eden. 2000. The Challenge of Collaborative Governance. Public Management: An International Journal of Research and Theory 2: 337-58. [CrossRef]

Klijn, Erik-Hans. 2001. Rules as Institutional Context for Decision Making in Networks: The Approach to Postwar Housing Districts in Two Cities. Administration \& Society 33: 133-64. [CrossRef]

Klijn, Erik-Hans, Joop Koppenjan, and Katrien Termeer. 1995. Managing networks in the public sector: A theoretical study of management strategies in policy networks. Public Administration 73: 437-54. [CrossRef]

Koppenjan, Joop, and Erik Hans Klijn. 2016. Governance Networks in the Public Sector. London: Routledge.

Laclau, Ernesto, and Chantal Mouffe. 1985. Hegemony and Socialist Strategy: Towards a Radical Democratic Politics. London: Verso.

Lawrence, Thomas B. 2008. Power, institutions and organizations. In Sage Handbook of Organizational Institutionalism. Edited by R. C. Greenwood, C. Oliver, K. Sahlin and R. Suddaby. London: Sage, pp. 170-97.

Lawrence, Thomas B., Cynthia Hardy, and Nelson Phillips. 2002. Institutional effects of interorganizational collaboration: The emergence of proto-institutions. Academy of Management Journal 45: 281-90.

Meyer, John W., and Brian Rowan. 1977. Institutionalized Organizations: Formal Structure as Myth and Ceremony. American Journal of Sociology 83: 340-63. [CrossRef]

Nye, Joseph S. 1990. Soft Power. Foreign Policy 80: 153-71. [CrossRef]

Ostrom, E. 2011. Background on the Institutional Analysis and Development Framework. Policy Studies Journal 39 : 7-27. [CrossRef]

Pettit, Jethro. 2010. Multiple Faces of Power and Learning. IDS Bulletin 41: 25-35. [CrossRef]

Pfeffer, Jeffrey, and Gerald R. Salancik. 2003. The External Control of Organizations: A Resource Dependence Perspective. Stanford: Stanford University Press.

Phillips, Nelson, Thomas B. Lawrence, and Cynthia Hardy. 2000. Inter-organizational Collaboration and the Dynamics of Institutional Fields. Journal of Management Studies 37. [CrossRef]

Provan, Keith G., and Patrick Kenis. 2007. Modes of Network Governance: Structure, Management, and Effectiveness. Journal of Public Administration Research and Theory 18: 229-52. [CrossRef]

Purdy, Jill M. 2012. A Framework for Assessing Power in Collaborative Governance Processes. Public Administration Review 72: 409-17. [CrossRef] 
Scharpf, Fritz W. 1978. Interorganizational Policy Studies: Issues, Concepts and Perspectives. In Interorganizational Policy Making. Limits to Coordination and Central Control. London: Sage.

Schön, Donald A., and Martin Rein. 1994. Frame Reflection: Towards the Resolution of Intractable Policy Controversies. New York: Basic Books.

Schouten, Greetje, Pieter Leroy, and Pieter Glasbergen. 2012. On the deliberative capacity of private multi-stakeholder governance: The Roundtables on Responsible Soy and Sustainable Palm Oil. Ecological Economics 83: 42-50. [CrossRef]

Scott, W. Richard. 2008. Institutions and Organizations: Ideas, Interests, and Identities. London: Sage.

Selsky, John W., and Barbara Parker. 2005. Cross-Sector Partnerships to Address Social Issues: Challenges to Theory and Practice. Journal of Management 31: 849-73. [CrossRef]

Sørensen, Eva, and Jacob Torfing. 2007. Theories of Democratic Network Governance. Regulation XIV: 3565. [CrossRef]

Stone, Deborah A. 2002. Decisions. In Policy Paradox. The Art of Political Decision-Making. Glenview: Scott, pp. 232-57.

Thornton, P., and W. Ocasio. 2008. Institutional logics. In Handbook of Organizational Institutionalism. Edited by R. Greenwood, C. Oliver, K. Sahlin-Andersson and R. Suddaby. Thousand Oaks: Sage, pp. 99-129.

Torfing, Jacob, B. Guy Peters, Jon Pierre, and Eva Sørensen. 2012a. Interactive Governance. Advancing the Paradigm. Oxford: Oxford University Press.

Torfing, Jacob, B. Guy Peters, Jon Pierre, and Eva Sørensen. 2012b. Power and politics in interactive governance. In Interactive Governance: Advancing the Paradigm. Oxford: Oxford University Press.

Townley, B. 1997. The institutional logic of performance appraisal. Organization Studies 18: 261-85. [CrossRef]

Trist, Eric. 1983. Referent Organizations and the Development of Inter-Organizational Domains. Human Relations 36: 269-84. [CrossRef]

Van Buuren, Arwin, Martinus Vink, and Jeroen Warner. 2014. Constructing Authoritative Answers to a Latent Crisis? Strategies of Puzzling, Powering and Framing in Dutch Climate Adaptation Practices Compared. Journal of Comparative Policy Analysis: Research and Practice 18: 70-87. [CrossRef]

Van Huijstee, Mariette, and Pieter Glasbergen. 2010. Business-NGO Interactions in a Multi-Stakeholder Context. Business and Society Review 115: 249-84. [CrossRef]

Van Hulst, Merlijn, and Dvora Yanow. 2014. From policy "frames" to "framing": Theorizing a more dynamic, political approach. The American Review of Public Administration 46: 92-112. [CrossRef]

Vangen, Siv, John Paul Hayes, and Chris Cornforth. 2015. Governing Cross-Sector, Inter-Organizational Collaborations. Public Management Review 17: 1237-60. [CrossRef]

Vansina, Leopold, T. C. B. Taillieu, S. G. L. Schruijer, W. Pasmore, and R. Woodman. 1998. “Managing” multiparty issues: Learning from experience. Research in Organizational Change and Development 11: 159-81.

Vink, Martinus Janszoon. 2015. Navigating Frames: A Study of the Interplay between Meaning and Power in Policy Deliberations over Adaptation to Climate Change. Wageningen: Wageningen University.

Visseren-Hamakers, Ingrid Jacoba, Pieter Leroy, and Pieter Glasbergen. 2010. Conservation partnerships and biodiversity governance: Fulfilling governance functions through interaction. Sustainable Development 20: 264-75. [CrossRef]

Weick, Karl E. 1995. Sensemaking in Organizations. Thousand Oaks: Sage.

Woodhill, A. J., and S. M. van Vugt. 2011. Facilitating MSPs-A Sustainable Way of Changing Power Relations? In Guidebook for MSP Facilitation. Edited by GIZ South Africa. Eschborn: Deutsche Gesellschaft für Internationale Zusammenarbeit (GIZ), pp. 36-46.

(c) 2018 by the authors. Licensee MDPI, Basel, Switzerland. This article is an open access article distributed under the terms and conditions of the Creative Commons Attribution (CC BY) license (http://creativecommons.org/licenses/by/4.0/). 